\title{
State of the Art in Educational Games Virtualization
}

\author{
Wilk Oliveira dos Santos ${ }^{12}$, Clovis Gomes da Silva Junior ${ }^{3}$ \\ ${ }^{1}$ Computer Institute - Federal University of Alagoas (UFAL) - Maceió, AL - Brazil \\ ${ }^{2}$ Department of Computer Science - University of Saskatchewan (U of S) - Saskatoon, SK - \\ Canada \\ ${ }^{3}$ University of Pernambuco (UPE) - Garanhuns, PE - Brazil \\ wos@ic.ufal.br, clovis.gomes@upe.br
}

\begin{abstract}
Game Virtualization is a process of digital versions creation for traditional/ physical games. In education, this process aims to create digital versions for traditional/ physical educational games, keeping psychological and pedagogical concepts from traditional version, as well as associate these concepts to contemporary game design elements. In the last years, a series of studies and efforts have been done in this field, making room to important discussions regarding the results obtained and perspectives to future works. In this sense, this paper presents a state of the art in Educational Game Virtualization, as well as some discussions, challenges and directions to new studies in this field.
\end{abstract}

Keywords: Educational Games Virtualization; Educational Games; State of the Art

Resumo. Virtualização de Jogos é um processo para criação de versões digitais para jogos tradicionais/ físicos. Em educação, este processo tem o objetivo de criar versões digitais para jogos educativos tradicionais/ físicos, mantendo os princípios pedagógicos e psicopedagógicos da versão tradicional do jogo, associando estes princípios as mecânicas contemporâneas de game design. Nos últimos anos, uma série de estudos e esforços têm sido conduzidos neste domínio, abrindo espaço para impotentes discussões relacionadas aos resultados obtidos e perspectivas para trabalhos futuros. Neste sentido, este artigo apresenta um estado da arte em Virtualização de Jogos Educativos, bem como algumas discussões, desafios e direções para novos estudos neste domínio.

Palavras-chave: Virtualização de Jogos Educativos; Jogos Educativos; Estado da Arte

\section{Introduction}

In the last decades, the international industry of game development has been increasing, becoming an important worldwide industry. According to a recent report of Entertainment Software Association (ESA 2015), only in the United States, there are approximately 155 million of players moving, in 2014, approximately $\$ 22.41$ billion around the word. Additionally, another interesting recent study showed that $74 \%$ of $K-8^{1}$ teachers use digital games in the classroom (Lofgren 2015), enabling a considerable growth of the Educational Games industry in the last years.

\footnotetext{
${ }^{1}$ K-8 schools are schools in the United States that enroll students from kindergarten/pre-K (age 5) through 8th grade (up to age 14), combining the typical elementary school (K-5) and junior high or middle school (6-7-8).
} 
In the academic context, a series of recent studies have been done in order to investigate effects of video games in different educational aspects (e.g. Anderson et al. (2010), Scoresby and Shelton (2011) and others). These studies have highlighted a series of discussions related to video games positive effects in student's learning, such as: game fullness, motivation and others; and negative effects, such as: violence, social interaction absence and extreme appreciation of "digital" (digital activities conducted using some kind of technological device), in detriment to "traditional" (traditional (physical/ manual) activities).

Recent studies addressing Game Virtualization, (e.g. Santos et al. (2015) and Oliveira and Silva Junior (2015)), in order to create digital versions to traditional/physical Educational Games, aim to keep the pedagogical and psychological aspects from traditional/physical game, and associate these aspects to contemporary game design elements. Like this, recent studies have showed a different benefits of virtualized games, as well as highlighted a series of discussions related to design, application and evaluation of Educational Games developed based on Virtualization Games.

However, Educational Games Virtualization is a current theme, whose most of studies are recent works, generally pointed about Educational Game development to specifically contents, such as: Math or Biology. Like this, it is important to obtain a general view of Educational Games Virtualization, in order to understand which are the possible contributions of studies, as well as provide directions to future works. In this context, this study aims to present a state of the art on Educational Games Virtualization, the work also present some challenges and direction to future studies.

\section{Background}

In this section, we present the main topics addressed in this study: Educational Games and Educational Games Virtualization, as well as some related works.

\subsection{Educational Games}

Over the last 20 years, computer games have been increasingly replaced the more traditional games as leisure activities, and have had a transformational impact on how we spend our leisure time (Connolly et al. 2012). According to these authors, Educational Games provide engaging activities and it seems like that, far from waning, interest in games for leisure is still growing.

At this point, in the last decades, Educational Games have been used in many teaching contexts of different topics as: Business, Geography, History, and others (Connolly et al. 2012), as well as studied in different perspectives as violence (Anderson and Gentile 2014), learning (Linehan et al. 2014), playfulness (Scoresby and Shelton 2011) and others.

According to recent studies, a series of empirical results related to games-based learning has shown that despite the overwhelming publicity given to the negative impact of games, like most technologies before them, computer games can have both positive and negative impacts (Connolly et al. 2012). These results are important to demonstrate not only the efficacy of games in educational context, but also to highlight the importance of new studies in different kind of Educational Games.

\subsection{Educational Games Virtualization}

In the contemporary world, the idea of 'virtualization' is considered and studied by philosophy, psychology, physics, biotechnology, arts, and others (Kerimbayev 2015), 
increasing topics related to virtualization in different contexts as social life, industry and education. In this perspective, Educational Games Virtualization is a process to create digital versions for traditional/physical Educational Games before used to teaching of a determined topic. The main goals of Educational Games Virtualization are keep/preserve the aspects of the traditional/physical version of the educational games version and combine these aspects with the contemporary game design elements, in order to increase students' learning.

Educational Games Virtualization can be used in different contexts and be support in different educational topics. According to Oliveira and Silva Junior (2015), the Educational Games Virtualization process should be start with the choice of the traditional educational game and end with the process of game evaluation, in order to identify if the educational game (in the digital version) keeps/ preserves the main aspects from traditional/physical game version, as well identify if the game can be increase students' learning.

According to Santos et al. (2013) and Santos et al. (2015) this process involves a multidisciplinary team, with professionals from Computer Science (especially HumanComputer Interaction (HCI)), Pedagogy, Psychology and those from specific educational games application fields, for instance Mathematic, Language, Biology, and others, in order to auxiliary the Educational Game Virtualization process. The concept of Educational Virtualization Game in summarized on the conceptual map presented in the Figure 1.

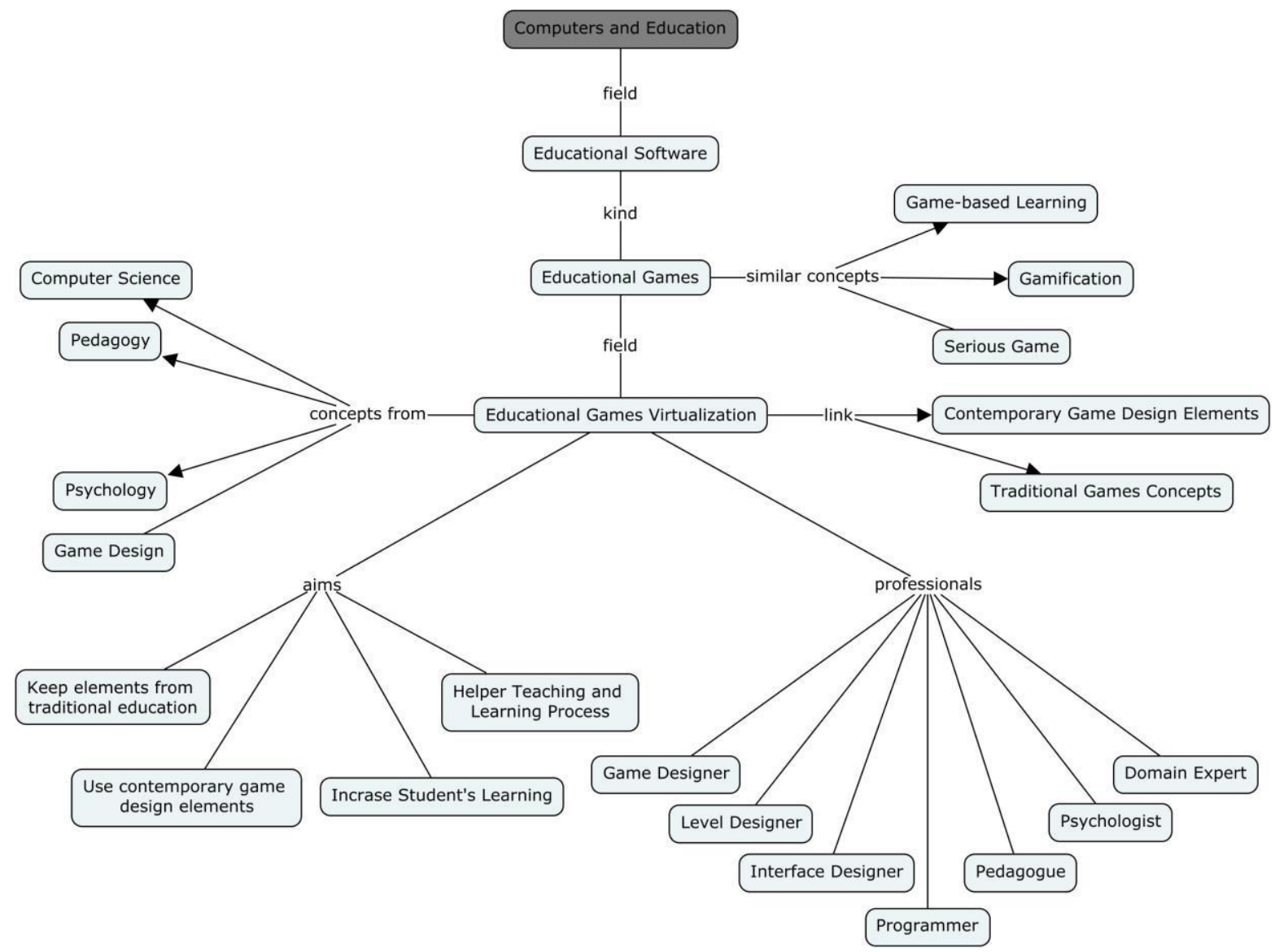

Figure 1: Conceptual map of Educational Games Virtualization

\subsection{Related Works}

Some related works were considered in this study, Cabreira and Aquino (2006) for instance, highlighted the "learning virtualization" concept, in others words, the process of virtualization of education, and the replacement of traditional educational activities for digital educational 
activities, also highlighting that if the teachers use traditional activities in the classroom, out of actually context experienced for the students, the activity can be frustrate the students and teachers.

Santos and Silva Junior (2016) proposed five challenges for Game Virtualization Applied to Educational Games, themselves conducted a study regarding the aspects of Educational Game Virtualization and the contemporary problems in this field, in order to proposed a series of challenges and guidelines to future works solve these problems.

The first study mentioned highlights the importance of Educational Game Virtualization in the contemporary educational scenario, specially, in order to provide to students, important traditional educational activities, adapted to actual student's reality. The second study represents an important step to this field, however, highlight only challenges and directions to future studies, without present a state of the art regarding Educational Games Virtualization. Therefore, using results obtained in the papers cited, this study keeps the discussions before started, linked to state of the art in Educational Game Virtualization.

\section{Educational Game Virtualization}

This section aims to present the state of the art in the field of Educational Games Virtualization, addressing the state of the art, recent efforts in this field, general outlook, as well as some challenges and directions to future studies.

\subsection{State of the Art}

In the last few years, several studies have been done in order to develop and evaluate Educational Games based on the Educational Games Virtualization process. Generally, these studies are conducted in the context of mathematics education and in order to implement games capable to increase students' learning during the elementary school and high school.

Given the background, Santos et al. (2013) proposed a process of Virtualize Educational Games used in previous decades to teach mathematical concepts. With this proposal, authors summarize the importance of keeping the main concepts of traditional/physical game version, as well as associate these concepts to contemporary digital game elements. Since this, a series of studies have been done with aim to implement/virtualize Educational Games based on this process.

Togni et al. (2009) presented an Educational Game to mathematics teaching in elementary schools that was developed based on the Meaningful Learning Theory, and was used with students in real context. However, they do not present concerns related to Computational and Pedagogical evaluation. In a similar study, Zorzal et al. (2008) showed a series of Educational Games virtualized using Augmented Reality (AR) resources, but do not presented concerns related to pedagogical aspects of games.

Recently, in order to solve the problems shown before, Santos et al. (2015) and Oliveira and Silva Junior (2015) proposed two Educational Games for mathematics teaching (called "Conquering with the Rest" and "Challenge with Sticks") developed based on the Educational Games Virtualization. These works were developed to elementary school students and were evaluated in real life by students and teachers.

The studies shown before do not present concerns related to methodologies to game virtualization process and game evaluation, as well as do not presented concerns related to the concepts maintenance of traditional games and influences of educational game in the students' learning. Moreover, both studies before mentioned focused in mathematics teaching domain. 


\subsection{Recent Efforts}

As mentioned in the last section, some efforts have been conducted in this field in the last years. Togni et al. (2009) developed a game based on traditional card game, aiming to teach basic concepts of geometry (See Figure 2). Oliveira et al. (2015) developed a game named Conquering with the Rest (original name in Portuguese: Conquistando com o Resto) aiming to teach concepts of division to elementary students (see Figure 3). Santos et al. (2015) proposed and developed a game named Challenges with Sticks (original name in Portuguese: Desafios com Palitos) that provide different challenges to teach concepts of geometry, numerical conversion, logical reasoning, and others (See Figure 4).

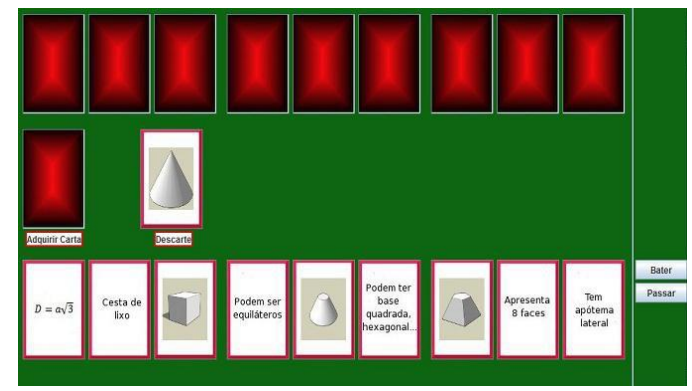

Figure 2: Game Geometric Piff

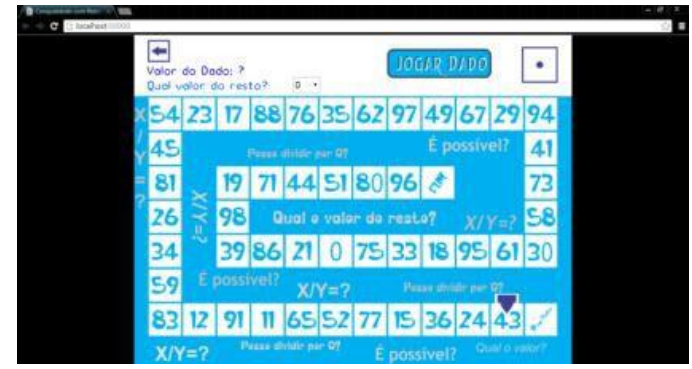

Figure 3: Game Conquering with the Rest

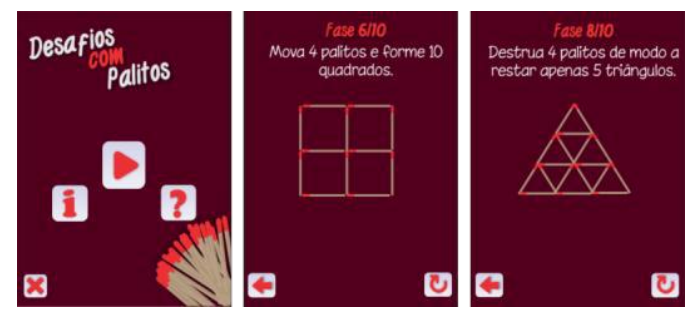

Figure 4: Game Challenges with Sticks

\subsection{General Outlook}

Based on content previously addressed, a series of points can be perceived and discussed. Is notorious for instance that besides the "learning virtualization" be a several discussed theme in the last years, the concept of Educational Games Virtualization, is a contemporary topic, initiated less than a decade, especially when Santos and Silva Junior (2013) and Santos et al. (2013) proposed the Educational game Virtualization, as a possibility to used traditional Educational Games, in the contemporary classroom, keeping Pedagogical and Psychological aspects of traditional game, allies to contemporary game design elements.

However, because the youth of field, studies until now done, are generally focused in specific points and specific domains, such as: games virtualization to teach math (generally specific contexts (e.g. geometry, division or logical reasoning)) to students in elementary school. Studies recently proposed in this field, generally are implemented using 
methodologies to game development and game evaluation, from others kind of games, generally, without present concerns related to specific point of Educational Games Virtualization.

The constructs preview addressed are important in order to confirm the challenges proposed by Santos and Silva Junior (2016) (see section 4.4), and allow understand that the Educational Game Virtualization is a young and current topic, with a series of interesting studies developed, and a topic capable to provide important insights to Computers and Education in the next years, however, with a series of challenges to be addressed in future studies in this field.

\subsection{Challenges and Directions to Future Studies}

Since the results obtained in this state of the art, was possible identify a series of challenges to field of Educational Games Virtualization. Initially, the results also provide to confirm the challenges proposed by Santos and Silva Junior (2016), that proposed five current challenges for Games Virtualization applied to Educational Games Virtualization and present a lot of guideline for each challenge proposed. Following we present the challenges confirmed in this state, the motivations regarding the challenges and guidelines to these challenges will be shown in the Table 1 and Table 2 respectively.

Challenges proposed by Santos and Silva Junior (2016): (i) design of methodologies for educational games virtualization, (i.i) design of methodologies for educational game evaluation, (i.ii) resources recommendation for Educational Games Virtualization, (ii) multidisciplinary of educational games virtualization, and (iii) professional training to Educational Games Virtualization.

Table 1: Challenges and Motivations (synthesized of Santos and Silva junior 2016)

\begin{tabular}{l|l}
\hline Challenges & \multicolumn{1}{c}{ Motivation } \\
\hline In the last years, some studies have been made addressing Educational Games Design based \\
on Games Virtualization. However, these studies present different methodologies and \\
process for the development of games, or use others methodologies from traditional game \\
design. On the other hand, Educational Games Virtualization, different of conventional \\
Educational Games Development, use concepts from different fields as Pedagogy, \\
Psychology, Computer Science and others.
\end{tabular}




\begin{tabular}{l|l}
\hline & $\begin{array}{l}\text { Recently, a series of studies addressing Educational Games Virtualization have been done. } \\
\text { However, majority of studies have been carried in the Math domain. On the other hand, } \\
\text { considering the concept of Game Virtualization, many others domains use/used traditional } \\
\text { games in classroom to increase students' learning in several activities, as well as to improve } \\
\text { the involvement of the students, in domains for instance: Biology, Geography, Literature, } \\
\text { and others. }\end{array}$ \\
\hline & $\begin{array}{l}\text { Professional training has become a big challenge in the industry and education in the last } \\
\text { years. In the past few years, various studies have been conducted to provide professional } \\
\text { training resources in different domains, inclusive in the Educational Game industry. Starting } \\
\text { with the updates before showed, as well as increasing specifics points, for instance: } \\
\text { multidisciplinary team, different evaluation process, integration with educational context, } \\
\text { and others. Educational Game industry suffered even more with this updates and was } \\
\text { necessary to invest annual big amounts with training of professionals. }\end{array}$ \\
\hline
\end{tabular}

Table 2: Challenges and Guidelines (synthesized of Santos and Silva junior 2016)

\begin{tabular}{|c|c|}
\hline Challenges & Guidelines \\
\hline 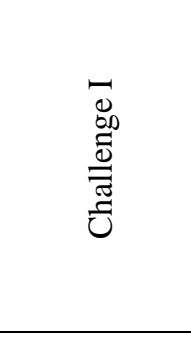 & $\begin{array}{l}\text { (i) methodologies must be implemented with multidisciplinary teem and collaboration of } \\
\text { professionals of Game Design, Computer Science, Psychology and Pedagogy, in order to } \\
\text { aggregate different knowledge areas and implement a methodology with potential scientific } \\
\text { and industrial; ( } \mathrm{ii} \text { ) methodologies hereafter proposed must be evaluated by different } \\
\text { professionals in different academicals and industrial scenarios to develop a methodology } \\
\text { able to be used in both contexts; (iii) methodologies hereafter proposed should provide } \\
\text { resources to virtualize Educational Games for different courses, not being addressed to } \\
\text { specifically contexts. }\end{array}$ \\
\hline 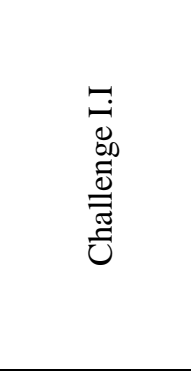 & $\begin{array}{l}\text { (i) methodologies hereafter proposed should develop with professionals of different domains } \\
\text { as: Pedagogy, Psychology and Computer Science (especially Software Engineering and } \\
\text { HCI), in order to provide a methodology capable to evaluate games according to different } \\
\text { criteria, from Pedagogy, Psychology and Computer Science (HCI); (ii) methodologies } \\
\text { hereafter proposed should provide minimally the following resources: evaluate if the game } \\
\text { keeps the Pedagogical and Psychological principles allied to contemporary game design } \\
\text { elements, evaluate the game quantitatively and qualitatively in aspects of Computers Science } \\
\text { (specially HCI) and Pedagogical aspects, as well as evaluate if the game contributes to } \\
\text { students' learning. }\end{array}$ \\
\hline 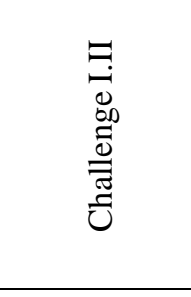 & $\begin{array}{l}\text { (i) future studies that aim to identify programming languages, tools, engines and general } \\
\text { resources should be developed with empirical metrics in order to provide resources to } \\
\text { futures replications in different contexts; ( } \mathrm{ii} \text { ) studies hereafter conducted to identify } \\
\text { resources to development of Educational Games based in Virtualization Games should be } \\
\text { developed with partnerships professionals of Science Computers and Education, in order to } \\
\text { recommend resources capable to facilitate the process of development and maintenance of } \\
\text { Educational Games (integration between technical and educational concepts). }\end{array}$ \\
\hline 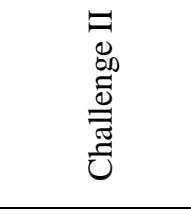 & $\begin{array}{l}\text { (i) games hereafter virtualized should be developed and evaluated according to specifics } \\
\text { methodologies of Educational Game Virtualization, in order to permit a robust evaluation in } \\
\text { Computational and Pedagogical aspects, as well as permit future applications of works; (ii) } \\
\text { game hereafter virtualized should be evaluated in different real contexts (with real classroom } \\
\text { and real students). }\end{array}$ \\
\hline 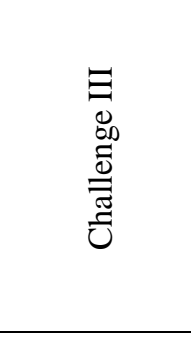 & $\begin{array}{l}\text { ( } i \text { ) before the importance of professionals to development of educational resources, we } \\
\text { consider necessary invest in the professional multidisciplinary capacitation and } \\
\text { specialization, in order to form professionals capable to deal with different situations (in the } \\
\text { industry and academy), as well as they will be able to deal with the integration of technology } \\
\text { (game design approach), and education; ( } i i) \text { futures research groups, companies and others } \\
\text { professional groups interested in Educational Games Virtualization can invest in the } \\
\text { integration academy-industry, in order to training professionals capable to deal with these } \\
\text { different scenarios. }\end{array}$ \\
\hline
\end{tabular}


In addition to confirming these challenges, this state of the art allowed to find others important challenges in this field. Actually, few works conduct empirical studies in order to evaluate educational game (virtualized) influences in students, for instance, evaluate if the game can be increase student's learning, student's motivation or if the students reach some good emotional experience, such as: gamefulness (Deterding et al. 2011) or flow state (Csikszentmihalyi 1990).

Since that recent studies have highlighted the importance of to analyze these concepts in Computers and Education context (i.e. Santos et al. 2015), as well the importance of evaluate if the educational game really provide positive consequences to students (i.e. Silva Neto et al. 2013), we proposed that another important challenge for Virtualization Games applied to Educational Games is conduct empirical studies in order to the educational game regarding these concepts, as well as perhaps, compare the virtualized game with traditional game in different contexts. Figure 2 synthetize the challenges proposed by Santos and Silva Junior (2016) and the challenges identified in this study.

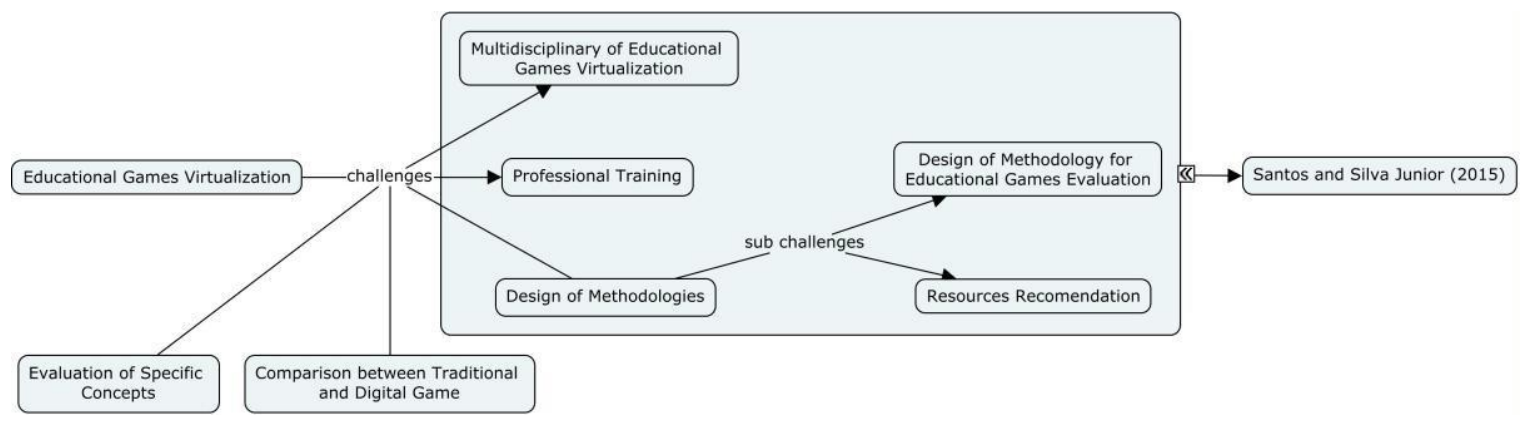

Figure 5: Conceptual map of Educational Games Virtualization Challenges

\section{Limitations}

In order to provide the conduction of new studies in this field, based on results presented in this paper, as well as to provide to researchers an overview regarding the conduction of this study, following we explain about the study' limitations.

The main limitation of this state of art is positioned in the studies obtainment, the state of the art was obtained through reading of paper from important Brazilian conferences and journals, however, was not conducted a systematic mapping, may have been left out some studies in this field. In order to minimize this limitation, all discussions presented in the paper were conducted for professionals with expertise in this field.

\section{Concluding Remakes}

In the past few years, Educational Game Virtualization have been addressed as a promising topic of Educational Game, especially to provide to students, pedagogical and psychological aspects of traditional/physical games, allied to modern game design approaches (e.g. Santos et al. (2015) and Oliveira and Silva Junior (2015)). However, these studies recently conducted in Educational Virtualization Games, open a series of discussions regarding this field. In this way, this paper presented a state of the art in Educational Game Virtualization, as well as some challenges and insights to future studies in this domain.

The state of art presented in this paper showed that studies recently conducted regarding Educational Games Virtualization are generally focused in specifics points and specifics domains, such as: games virtualization to teach math (generally specific contexts (e.g. division or logical reasoning)) to students in elementary school, as well the studies, 
generally, are developed and evaluated based on methodologies from traditional game design, without present concerns related to specific points of Educational game Virtualization, such as, if the game virtualized, keep the main concepts from the traditional game.

The state of the art presented in the paper, also allowed confirm a series of challenges for Educational Games Virtualization recently proposed $((i)$ design of methodologies for educational games virtualization, (i.i) design of methodologies for educational game evaluation, (i.ii) resources recommendation for Educational Games Virtualization, (ii) multidisciplinary of educational games virtualization, and (iii) professional training to Educational Games Virtualization) and identify others current challenges, (i.e. evaluation of specific concepts and comparison between digital and traditional game version).

Finally, as general recommendation and future studies, we highlight the importance of to conduct a Systematic Literature Review applied to Educational Games Virtualization, in order to obtain an empirical view of this field and compare with the results presented in this paper, as well as the development of new research in order to solve the challenges presented in this paper.

\section{References}

Anderson, C. A., \& Gentile, D. A. (2014). Violent Video Game effects on Aggressive thoughts, feelings, physiology, and Behavior. Media Violence and Children: A Complete Guide for Parents and Professionals, 229.

Anderson, C. A., Shibuya, A., Ihori, N., Swing, E. L., Bushman, B. J., Sakamoto, A., \& Saleem, M. (2010). Violent video game effects on aggression, empathy, and prosocial behavior in eastern and western countries: a meta-analytic review. Psychological bulletin, 136(2), 151.

Cabreira, L. G., \& Aquino, O. R. (2006). Jogos Eletrônicos: A virtualização do brincar na perspectiva dos professores de $3^{\mathrm{a}}$ e $4^{\mathrm{a}}$ séries do ensino fundamental I de uma escola particular de Maringá/PR. Educação em Revista, 7(1-2), 85-102.

Connolly, T. M., Boyle, E. A., MacArthur, E., Hainey, T., \& Boyle, J. M. (2012). A systematic literature review of empirical evidence on computer games and serious games. Computers \& Education, 59(2), 661-686.

Csikszentmihalyi M. (1990) "Flow: The psychology of optimal experience". New York: Harper-Collins.

Deterding, S., Dixon, D., Khaled, R., \& Nacke, L. (2011, September). From game design elements to gamefulness: defining gamification. In Proceedings of the 15th international academic MindTrek conference: Envisioning future media environments (pp. 9-15). ACM.

Essential facts about the computer and video game industry: 2015 sales, demographic and usage data. Entertainment Software Association, 2015.

Kerimbayev, N. (2015). Virtual learning: Possibilities and realization. Education and Information Technologies, 1-13.

Linehan, C., Bellord, G., Kirman, B., Morford, Z. H., \& Roche, B. (2014, October). Learning curves: analysing pace and challenge in four successful puzzle games. In Proceedings of the first ACM SIGCHI annual symposium on Computer-human interaction in play (pp. 181-190). ACM. 
Lofgren, K. (2015) 2015 Video Game Statistics \& Trends Who's Playing What \& Why?. Available in: http://www.bigfishgames.com/blog/2015-global-video-game-stats-whosplaying-what-and-why/. Accessed: 09/March/2016.

Oliveira, W., Neto, S., da Silva Junior, C. G., \& Bittencourt, I. I. (2015). Avaliação de Jogos Educativos: Uma Abordagem no Ensino de Matemática. In: Simpósio Brasileiro de Informática na Educação (Vol. 26, No. 1, p. 657).

Oliveira, W., \& da Silva Junior, C. G. (2015). Pesquisa, Desenvolvimento e Avaliação de um Jogo para o Ensino de Matemática, Baseado no Processo de Virtualização de Jogos. In Anais dos Workshops do Congresso Brasileiro de Informática na Educação (Vol. 4, No. 1, p. 145).

Santos, W. O., Bittencourt, I. I., Isotani, S., Silveira, F. I., Marques, L. B. (2015). Challenges of Flow Theory Applied to Computers in Education. In: IV Workshop of Challenges of Computer in Education. Recife - PE, Brazil.

Santos, W., Silva Neto, S. R., \& Silva Junior, C. G. (2013). Uso de Games no ensino da Matemática. Uma proposta de virtualização dos jogos tradicionais, para uso como mecanismo de apoio ao processo de ensino e aprendizagem. In: Anais do Simpósio Hipertexto e Tecnologias na Educação, Recife-PE.

Santos, W. O.; Silva Junior, C. G.; Barros, F. L. P. (2013). Processo de virtualização de jogos matemáticos tradicionais, para uso como ferramenta de auxilio ao processo de ensino e aprendizagem em escolas do agreste de Pernambuco. In: IV Encontro Anual de Tecnologia da Informação (EATI), Frederico Westphalen - RS, p. 312-316.

Santos, W. O.; Silva Junior, C. G. (2016). Challenges of Games Virtualization Applied to Educational Games. In: V Workshop of Challenges of Computers in Education. P. 597606. Porto Alegre - RS, Brazil.

Santos, W., O.; Souza, A., A.; da Silva, A., K., T.; Oliveira, M., L., S.; Silva Neto, S., R.; Rodrigues, A. N., Silva Junior, C. G. (2015) Development Process of an Educational Game: An experience in Brazil. In: XIV Brazilian Symposium of Games and Digital Entertainment. Teresina-PI, Brazil.

Scoresby, J., \& Shelton, B. E. (2011). Visual perspectives within educational computer games: effects on presence and flow within virtual immersive learning environments. Instructional Science, 39(3), 227-254.

Silva Neto, S. R., Santos, H. R., Souza A. A., Santos W. O. (2013) Jogos Educacionais como Ferramenta de Auxílio em Sala de Aula. In: Anais do Workshop de Informática na Escola (Vol. 1, No. 1, p. 130).

Togni, A. C., Rehfeldt, M. J. H., Bersch, M. E., Thomas, M. I. P., Poletti, C. F., \& Kronbauer, K. A. (2009). Piff geométrico: um objeto virtual de aprendizagem para o ensino de ciências exatas. RENOTE, 7(3), 45-52.

Zorzal, E. R., Kirner, C., Cardoso, A., Lamounier Jr, E., de Oliveira, M. R. F., \& Silva, L. F. (2008). Ambientes Educacionais Colaborativos com Realidade Aumentada. RENOTE, $6(2)$. 